\title{
Heme Metabolism and Turnover of Cytochrome P-450 in Tumor-Bearing Mouse Livers
}

\author{
Kie Ikeuchi, Masanobu ObaRa, Hideyasu HIRANO, \\ Sadao GotoH and Ken Higashi \\ Department of Biochemistry, School of Medicine, University of Occupational and \\ Environmental Health, Japan. Kitakyushu, 807, Japan
}

Abstract: $\quad$ Hepatic heme metabolism and in vitro translation of poly $(\mathrm{A})^{+} \mathrm{RNA}$ from livers were studied to elucidate the mechanism of the reduction of microsomal cytochrome P-450 in tumor-bearing mouse livers. Hepatic $\delta$-aminolevulinic acid synthase activity in male $\mathrm{C} 57 \mathrm{BL} / 6 \mathrm{~N}$ mice $(0.203 \mathrm{nmol} / \mathrm{mg}$ protein $/ \mathrm{h})$ at 8 days after the transplantation of Ehrlich ascites tumor cells was the same level as that of normal livers $(0.206 \mathrm{nmol} / \mathrm{mg}$ protein $/ \mathrm{h})$. On the other hand, hepatic heme oxygenase activity of tumor-bearing mice $(0.482 \mathrm{nmol} / \mathrm{mg}$ protein $/ 10 \mathrm{~min}) \mathrm{had}$ increased 8 days following i. p. transplantation of tumor cells when compared with that of normal mouse livers $(0.296 \mathrm{nmol} / \mathrm{mg}$ protein $/ 10 \mathrm{~min})$. SDS-gel electrophoresis of in vitro translation products of poly $(\mathrm{A}){ }^{+} \mathrm{RNA}$ extracted from membrane-bound polysomes of the livers from tumor-bearing mice showed no significant differences from that of normal controls in the region of cytochrome $\mathrm{P}-450$, that is, the molecular weight region of $\mathrm{Mr}=47,000-$ 60,000 , although microsomal protein content in this region estimated by Coomassie-blue staining was reduced. These results suggest that the decrease of heme biosynthesis or the translation of cytochrome P-450 mRNA played a very small part in the reduction of microsomal cytochrome $\mathrm{P}-450$ in tumor-bearing mice.

Key words: cytochrome $\mathrm{P}-450$, heme metabolism, poly $(\mathrm{A})^{+}$RNA, tumor-bearing mouse liver.

(Received 15 May 1985)

\section{Introduction}

The reduction of cytochrome P-450 in the microsomes of tumor-bearing animal livers have been reported by several investigators (Kato et al., 1968; Schacter \& Kurz, 1982; Higashi \& Ikeuchi, 1983; Raw, 1983). Microsomal cytochrome P-450 is composed of an undetermined number of monooxygenases with molecular weights between 47,000 and 60,000 (Haugen et al., 1976). Selective inductions of these isozymes by various xenobiotics have been frequently employed for the purification and characterization of specified forms of cytochrome P-450 in animal tissues (Haugen et al., 1976; Huang et al., 1976). On the other hand, the importance of microsomal cytochrome P-450 in the tissues of untreated animals have been noticed recently because these constitutive cytochrome P-450 must have their physiological substrates such as steroids and fatty acids. The reduction of constitutive cytochrome P-450 in the liver might contribute to the occurrence of cancerous cachexia. 
To elucidate the mechanism of the reduction of microsomal cytochrome P-450, we studied heme metabolism and in vitro translation of poly $(\mathrm{A})^{+}$RNA from livers of both normal and tumor-bearing mice. Previous reports by Schacter \& Kurz (1984) and Beck et al. (1982) suggested that decreased hepatic microsomal cytochrome P-450 content in tumor-bearing animals was due to reduced synthesis of this hemoprotein. However, direct determination of the mRNA content of constitutive cytochrome P-450 is not feasible at the present time because of lack of cDNA probes for all forms of constitutive cytochrome P-450. We prepared poly $(\mathrm{A})^{+}$RNA from membrane-bound polysomes because the endoplasmic reticulum is the principal site of synthesis for the integral microsomal proteins such as cytochrome P-450 (Chen \& Negishi, 1982). Our in vitro translation experiment suggested no significant decrease in the translation of cytochrome P-450 mRNA. We also observed enhanced heme oxidation activity in the livers of tumorbearing mice.

\section{Materials and Methods}

Animals and tumor transplantation: Male C57BL/6N mice, 5 to 6 weeks old, were purchased from Kyushu Experimental Animals Co., Kitakyushu. The mice were inoculated i.p. with Ehrlich ascites tumor cells (approx. $3 \times 10^{7}$ cells). Animals were starved overnight before sacrifice and livers were perfused with cold $0.9 \% \mathrm{NaCl}$ solution through the portal vein.

Delta-aminolevulinic acid synthase assay: Livers were homogenized in $1.15 \% \mathrm{KCl}$ containing $0.1 \mathrm{mM}$ EDTA, centrifuged at $8,000 \times \mathrm{g}$ for $15 \mathrm{~min}$ and supernatants were discarded. Pellets were frozen and thawed to disrupt subcellular organelles and resuspended in $37.5 \mathrm{mM}$ Tris- $\mathrm{HCl}, \mathrm{pH} 7.4(0.25 \mathrm{~g}$ of original weight $/ \mathrm{ml})$. A reaction mixture contained $75 \mathrm{mM}$ citrate, $37.5 \mathrm{mM}$ sodium phosphate buffer, $\mathrm{pH} 7.4,15 \mathrm{mM} \mathrm{MgCl}, 7.5$ $\mathrm{mM}$ EDTA, and $2.2 \mathrm{mM}$ pyridoxal 5'-phosphate and enzyme preparation. Duplicates of $300 \mu \mathrm{l}$ aliquots were incubated at $37^{\circ} \mathrm{C}$ for $1 \mathrm{~h}$. The $\delta$-aminolevulinic acid (ALA) that formed was determined after conversion to 2-methyl-3-acetyl-4-(3-propionic acid) pyrole as described by Sassa et al. (1979). The concentration of ALA was determined based on the difference at $553 \mathrm{~nm}$ and $650 \mathrm{~nm}$ using an extinction coefficient at $58 \mathrm{mM}^{-1} \mathrm{~cm}^{-1}$. Heme oxygenase assay: This enzyme activity was measured essentially according to the method described by Maines \& Kappas (1975). The incubation mixture $(6.0 \mathrm{ml})$ contained liver microsomes (12 to $30 \mathrm{mg}$ protein), liver cytosol (10 mg protein), heme (17 $\mu$ $\mathrm{M})$, NADPH generating system $(0.85 \mathrm{mM}$ glucose-6-phosphate, 3 units of glucose-6phosphate dehydrogenase), $\mathrm{MgCl}_{2}(2 \mathrm{mM})$, and phosphate buffer $(0.09 \mathrm{M}, \mathrm{pH}$ 7.4). The mixture was preincubated for $5 \mathrm{~min}$ at $37^{\circ} \mathrm{C}$ and then divided into two aliquots. To the test aliquot, NADP (final concentration, $0.8 \mathrm{mM}$ ) in $1 \% \mathrm{NaHCO}_{3}$ was added and to the reference incubation mixture only $1 \% \mathrm{NaHCO}_{3}$ was added. After 10 min incubation, the incubation mixture was scanned between 350 to $650 \mathrm{~nm}$. Bilirubin 
formation was calculated using an extinction coefficient of $40 \mathrm{mM}^{-1} \mathrm{~cm}^{-1}$ between 464 to $530 \mathrm{~nm}$.

Preparation of poly $(A)^{+} R N A$ : Five mice livers were homogenized in $50 \mathrm{ml}$ of $0.25 \mathrm{M}$ sucrose containing $25 \mathrm{mM}$ Tris-HCl, pH 7.4, $25 \mathrm{mM} \mathrm{NaCl}, 5 \mathrm{mM} \mathrm{MgCl}{ }_{2}$ and $500 \mu \mathrm{g} / \mathrm{ml}$ heparin. The homogenates were centrifuged at $15,500 \mathrm{rpm}(40,000 \times \mathrm{g})$ for $40 \mathrm{~min}$ in a $70 \mathrm{Ti}$ rotor (Beckman). The pellets containing membrane-bound polysomes were homogenized in $100 \mathrm{ml}$ of $0.1 \mathrm{M}$ Tris-HCl buffer, $\mathrm{pH} 9.0$ contaning $0.1 \mathrm{M} \mathrm{NaCl}, 2 \mathrm{mM}$ $\mathrm{Na}_{2}$ EDTA, $2 \mathrm{mM} \mathrm{MgCl} 2,500 \mu \mathrm{g} / \mathrm{ml}$ heparin, and $1 \%$ SDS and then mixed with $100 \mathrm{ml}$ of phenol/chloroform/isoamyl alcohol $[25 / 24 / 1,(\mathrm{v} / \mathrm{v} / \mathrm{v})]$. The aqueous phase was washed twice with phenol/chloroform/isoamyl alcohol mixture. RNA was precipitated by ethanol, washed twice with $70 \%$ ethanol, and dissolved in distilled water. The RNA was reprecipitated in $2 \mathrm{M} \mathrm{LiCl}$ at $-20^{\circ} \mathrm{C}$ overnight to remove heparin. After reprecipitation of RNA with ethanol, the poly $(\mathrm{A})^{+}$RNA was obtained by oligo(dT)-cellulose (Bethesda Res. Lab. Inc.) column as described by Aviv \& Leder (1972).

Cell-free translation and analysis of its products: Reticulocyte lysate was purchased from New England Nuclear. The reaction mixture $(25 \mu \mathrm{l})$ was incubated according to the assay protocol with $0.25 \mu \mathrm{g}$ of $\operatorname{poly}(\mathrm{A})^{+}$RNA from either normal or tumor-bearing mouse liver and $12.5 \mu \mathrm{Ci}$ of $\mathrm{L}-\left[{ }^{35} \mathrm{~S}\right]$-methionine. The translation reaction was carried out at $37^{\circ} \mathrm{C}$ for $1 \mathrm{~h}$ and mixed with an equal volume of Laemmli's sample buffer $0.125 \mathrm{M}$ Tris-HCl, pH 6.8, 4\% SDS, 20\% glycerol, 10\% 2-mercaptoethanol and $0.002 \%$ bromphenol blue) and immersed for $1.5 \mathrm{~min}$ in boiling water. Electrophoresis of the translation products was carried out as described by Laemmli (1970) with a slight modification, that is, separation gel $(7.5 \%)$ contained $0.5 \%$ of polymer of acrylamide to prevent cracking during the following procedures. After electrophoresis, the gel was immersed in $1 \mathrm{M}$ sodium salicylate (Chamberlain, 1979) containing $3 \%$ glycerol $(\mathrm{v} / \mathrm{v}$ ) for $1 \mathrm{~h}$, dried under a gel drier and exposed to Kodak RP/R X-ray film for $4-5$ days at $-80^{\circ} \mathrm{G}$.

Other assays: Cytochrome P-450 content in the microsomes was determined by the method of Omura \& Sato (1964). Protein was determined by the procedure of Lowrey et al. (1951) with bovine serum albumin as a standard.

\section{Results}

Changes of microsomal proteins and cytochrome P-450 contents:

The decrease of hepatic microsomal cytochrome P-450 was consistently observed from around 5 to 6 days after the tumor-inoculation (Table 1). The reduction of microsomal cytochrome P-450 was time-dependent, while the decrease of microsomal proteins was less significant. The cytochrome P-450 content at the 8th day after inoculation was approximately two-thirds of control value. For the following experiments, we decided to use livers from tumor-bearing mice at 8 days after tumor transplantation, because it is likely that the regulatory mechanism for both heme metabolism and turnover of microsomal 
Table 1. Changes of microsomal proteins and cytochrome P-450 contents.

\begin{tabular}{|c|c|c|c|c|}
\hline \multirow{2}{*}{ Animal } & \multirow{2}{*}{$\begin{array}{c}\text { Numbers } \\
\text { used }\end{array}$} & \multirow{2}{*}{$\begin{array}{c}\text { Microsomal } \\
\text { proteins } \\
\text { (mg/g wet wt.) }\end{array}$} & \multicolumn{2}{|c|}{ Cytochrome P-450 } \\
\hline & & & (nmol/mg prot.) & (nmol/g wet wt.) \\
\hline Normal & 28 & $\begin{array}{r}25.2 \pm 0.9^{b} \\
(100 \%)^{c}\end{array}$ & $\begin{array}{c}1.13 \pm 0.05^{\mathrm{b}} \\
(100 \%)\end{array}$ & $\begin{array}{c}27.8 \pm 0.7^{b} \\
(100 \%)\end{array}$ \\
\hline \multicolumn{5}{|c|}{ Tumor-bearing } \\
\hline $5-6$ days & 12 & $\begin{array}{l}24.2 \pm 1.8 \\
(96.0 \%)\end{array}$ & $\begin{array}{c}0.86 \pm 0.05 \\
(76.1 \%)\end{array}$ & $\begin{array}{c}21.1 \pm 1.9 \\
(75.9 \%)\end{array}$ \\
\hline $7-8$ days & 9 & $\begin{array}{l}23.1 \pm 1.3 \\
(91.7 \%)\end{array}$ & $\begin{array}{c}0.82 \pm 0.08 \\
(72.6 \%)\end{array}$ & $\begin{array}{l}18.6 \pm 0.6 \\
(66.9 \%)\end{array}$ \\
\hline $9-10$ days & 9 & $\begin{array}{l}23.3 \pm 1.8 \\
(92.5 \%)\end{array}$ & $\begin{array}{c}0.59 \pm 0.03 \\
(52.2 \%)\end{array}$ & $\begin{array}{c}13.5 \pm 0.8 \\
(48.6 \%)\end{array}$ \\
\hline $11-15$ days & 12 & $\begin{array}{l}21.6 \pm 1.0 \\
(85.7 \%)\end{array}$ & $\begin{array}{c}0.55 \pm 0.06 \\
(48.7 \%)\end{array}$ & $\begin{array}{c}11.1 \pm 1.2 \\
(39.9 \%)\end{array}$ \\
\hline
\end{tabular}

a: Microsomal proteins recovered from original liver weight $(g) \quad b$ : standard error

c: per cent of control

Table 2. Hepatic ALA synthase activity in normal and tumor-bearing mice

\begin{tabular}{lccc}
\hline \multirow{2}{*}{ Animal } & \multirow{2}{*}{$\begin{array}{c}\text { Number of } \\
\text { determinations }\end{array}$} & $\mathrm{nmol} / \mathrm{mg}$ prot./h & $\mathrm{nmol} / \mathrm{g}$ liver $/ \mathrm{h}$ \\
\hline Normal & 11 & $0.203 \pm 0.034^{\mathrm{a}}$ & $1.53 \pm 0.26^{\mathrm{a}}$ \\
Tumor-bearing & 17 & $0.206 \pm 0.018$ & $1.61 \pm 0.12$ \\
\hline
\end{tabular}

a: standard error

Table 3. Hepatic heme oxygenase activity in normal and tumor-bearing mice

\begin{tabular}{lccc}
\multirow{2}{*}{ Animal } & Number of & \multicolumn{2}{c}{ Heme oxygenase activity } \\
\cline { 3 - 4 } & 12 & $\mathrm{nmol} / \mathrm{mg}$ prot./10min & $\mathrm{nmol} / \mathrm{g}$ liver $/ 10 \mathrm{~min}$ \\
\hline Normal & 9 & $0.296 \pm 0.030^{\mathrm{a}}$ & $2.16 \pm 0.24^{\mathrm{a}}$ \\
Tumor-bearing & 9 & $0.482 \pm 0.039^{\mathrm{b}}$ & $3.28 \pm 0.12^{\mathrm{b}}$ \\
\hline
\end{tabular}

a: standard errors

b: value statistically different from the control value $(P<0.001)$

cytochrome P-450 would not be impared severely at this time point (Nakata et al., 1964). Tumor-bearing mice usually survive for about 3 weeks after the inoculation of ascites tumor cells.

Effect of tumor-bearing on hepatic $\delta$-aminolevulinic acid(ALA) synthase activity:

ALA synthase (EC 2.3.1.37), which is the rate-limiting enzyme in heme biosynthesis, was determined in the livers from either tumor-bearing mice or normal controls. Hepatic ALA synthase activity at 8 days after tumor-inoculation was the same level as that of control livers (Table 2). The specific values expressed as nmol of ALA synthesized per either $\mathrm{mg}$ protein or original liver weight between tumor-bearing and control mice were similar at least under the conditions examined. 


\section{Effect of tumor-bearing on hepatic heme oxygenase activity:}

In the assay of heme oxygenase (EC 1.14.99.3) activity, the cytosol fraction was utilized as the source of biliverdin reductase (EG 1.3.1.24) to convert biliverdin to bilirubin. According to the method described by Maines \& Kappas (1975), liver microsomes were once prepared by centrifugation and the resulting pellets were resuspended in buffer. This microsomal preparation and an aliquot of cytosol were used as enzyme sources as described in Materials and Methods. The average values of microsomal proteins recovered from the original liver weight was about $25 \mathrm{mg} / \mathrm{g}$ and that of cytosol was about $80 \mathrm{mg} / \mathrm{g}$, respectively.

Hepatic heme oxygenase activity was determined in the livers of normal mice and of tumor-bearing mice at 8 days after implantation of ascites tumor cells. This enzyme is also rate-limiting for heme degradation, as well as ALA synthase for heme biosynthesis. Contrary to ALA synthase, the hepatic heme oxygenase activity of livers from tumor-bearing mice was increased to $0.482 \mathrm{nmol}$ of bilirubin formed $/ \mathrm{mg}$ microsomal protein/10 min as compared with that of nomal mouse livers, that is, $0.296 \mathrm{nmol} / \mathrm{mg}$ protein/10 $\min$ (Table 3).

Comparison of in vitro translation products of poly $(A)^{+} R N A$ :

Since microsomal cytochrome P-450 is synthesized on membrane-bound polysomes (Chen \& Negishi, 1982), we prepared poly(A) ${ }^{+}$RNA from these fractions. The membrane-bound polysomes were isolated from livers of either normal or tumor-bearing mice. Poly $(\mathrm{A})^{+}$RNA obtained from polysomes was used in a cell-free translation system of rabbit reticulocyte lysate in the presence of $\left[{ }^{35} \mathrm{~S}\right]$-methionine. The products were analyzed on SDS-gel electrophoresis. Densitometric scanning after the fluorography of the dried gels showed that the general patterns of $\left.{ }^{[35} \mathrm{S}\right]$-labeled microsomal proteins of livers from normal and tumor-bearing mice were essentially similar. Furthermore, no significant reduction or even slight increase of $\left[{ }^{35} \mathrm{~S}\right]$-radioactive materials were observed in the microsomal proteins around the cytochrome P-450 region $(\mathrm{Mr}=47,000$ to 60,000 daltons) of tumor-bearing animals as compared with those of normal controls (Fig. 1). This was an unexpected feature of tumor-bearing mouse liver, because both the total content of microsomal cytochrome P-450 (Table 1) and color-intensities of microsomal proteins stained by Coomassie brilliant blue in this region showed reproducible reduction in the livers obtained at 8 days after tumor transplantation (Fig. 2).

\section{Discussion}

The turnover of different forms of cytochrome P-450 might be regulated selectively in animal tissues. Previously, we (Higashi \& Ikeuchi, 1983) and other investigators (Kato et al., 1968; Schacter \& Kurz, 1982; Raw, 1983) have shown the reduction of hepatic microsomal cytochrome P-450 when animals have tumors in the extrahepatic regions. Our enzymatic analysis (Higashi \& Ikeuchi, 1983) on drug-metabolizing en- 


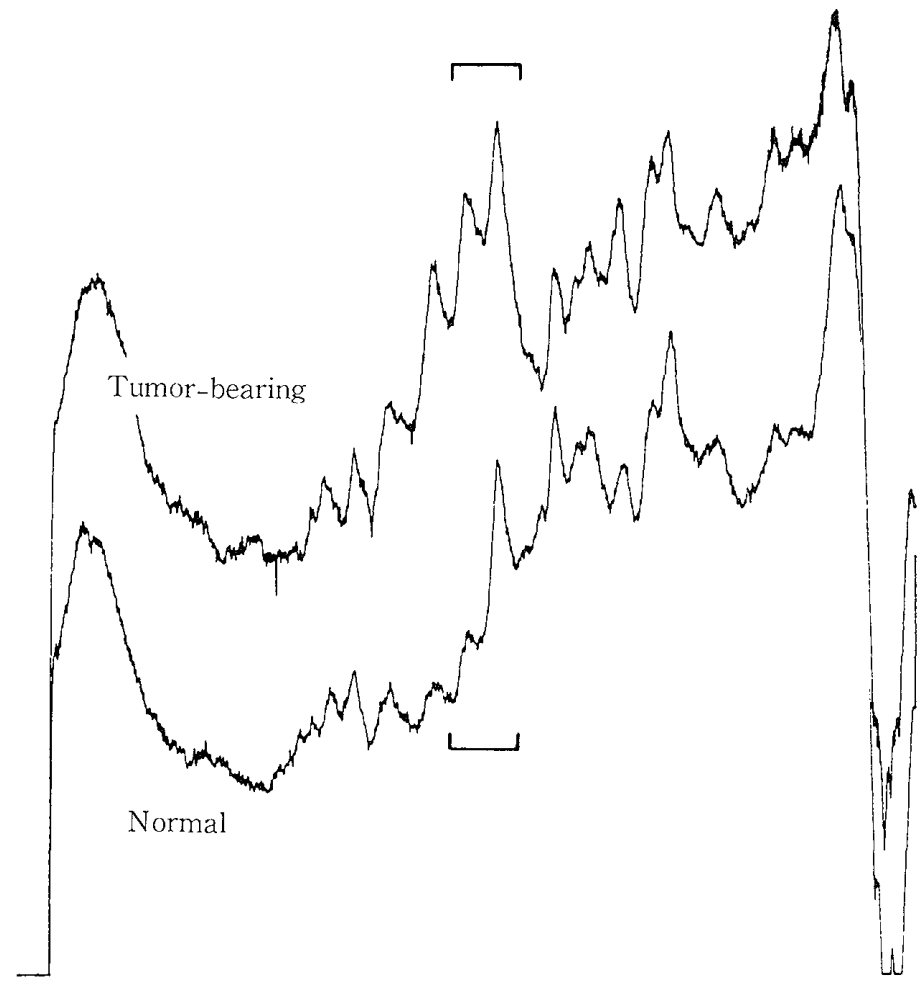

Fig. 1. Densitometric scanning of fluorography. In vitro translation products were analyzed on SDS-gel electrophoresis as described in Materials and Methods. Electrophoresis was from left to right. Bracket shows cytochrome P-450 region.

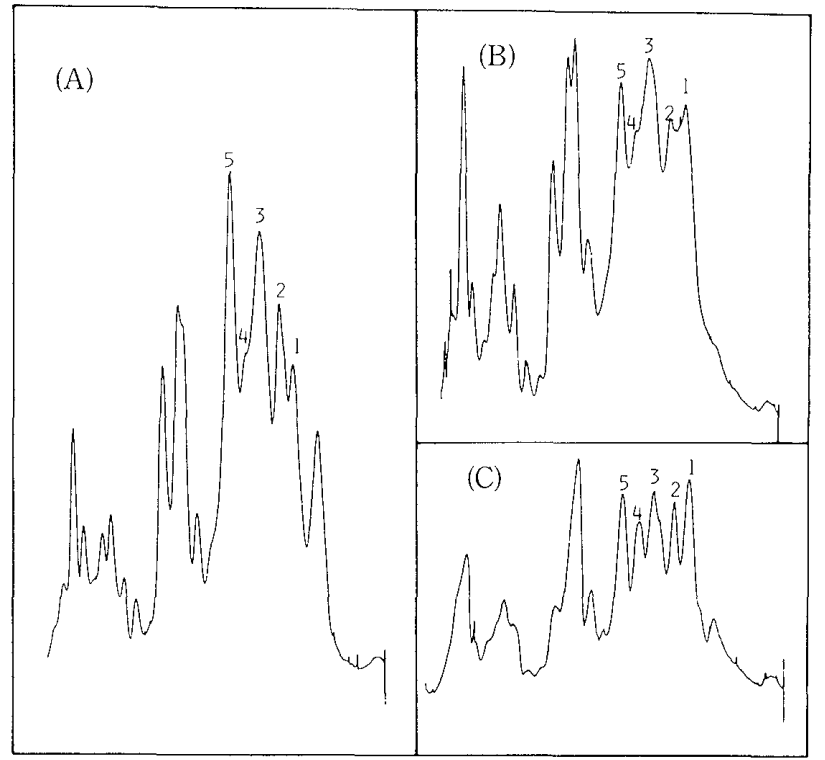

Fig. 2. Densitometric scanning $(550 \mathrm{~nm})$ of an SDS-polyacrylamide gel after electrophoresis of liver microsomes from control and tumor-bearing mice. (A) control, (B) tumor-bearing (8 days) and $(\mathrm{C})$ tumor-bearing (12 days) mice. The gel was stained with Coomassie brilliant blue. Peaks numbering from 1 to 5 were assumably representative of multiple forms of cytochrome P-450. Electrophoresis was from left to right. Only cytochrome $\mathrm{P}-450$ regions are shown in this figure. 
zymes in microsomes of livers from tumor-bearing animals suggest that the reduction of constitutive forms of microsomal cytochrome P-450 occurred selectively but not at random. We were interested in the mechanism of the turnover of cytochrome P-450 under physiological conditions. So far, a number of studies have been done on the biosynthesis of microsomal cytochrome P-450 after treatment with xenobiotics, such as phenobarbital (Rajamanickam et al., 1975) and methylcholanthrene (Chen \& Negishi, 1982). Heme metabolism in livers has been also investigated in many laboratories during induction of microsomal cytochrome P-450 by xenobiotics (DeMatteis \& Gibbs, 1972; Rajamanickam et al., 1975). On the other hand, much less attention has been paid to the turnover of constitutive forms of cytochrome P-450.

As described in the text, hepatic microsomal cytochrome P-450 content at 8 days after tumor implantation decreased to approximately two-thirds of normal controls. We observed no decrease of ALA synthase activity in the livers of tumor-bearing mice, while heme degradation was stimulated under these conditions. Previously, Beck et al. (1982) reported on the reduced incorporation of $\delta-\left[{ }^{1+} \mathrm{C}\right]$-ALA into both total microsomal proteins and in the cytochrome $\mathrm{P}-450$ region of SDS-gel in the tumor-bearing mouse liver. Direct determination of mRNA of constitutive forms of cytochrome P-450 is impossible due to the lack of cDNA-probes for these hemoproteins. There have been many reports on the significant changes of microsomal protein contents in the cytochrome $\mathrm{P}-450$ region $(\mathrm{Mr}=47,000$ to 60,000$)$ after the induction of these hemoproteins with xenobiotics (Guenthener \& Nebert, 1978; Peppriell, 1980; Ryan, et al., 1979). We observed the reduction of staining intensity of microsomal proteins in this cytochrome P-450 region even at 8 days after tumor-inoculation. However, the amounts of $\left[{ }^{35} \mathrm{~S}\right]$-labeled products of poly $(\mathrm{A})^{+}$RNA associated with membrane-bound polysomes did not reduce in tumorbearing animal livers as compared with those of normal controls. Although we did not determine the distribution of mRNA for cytochrome P-450 between the free form in cytosol and the translation-engaged form in polysomes (Chen \& Negishi, 1982), the transcriptions of cytochrome P-450 genes might not be reduced in the livers of tumor-bearing animals.

One possible explanation for the present results is that the cytochrome P-450 apoproteins not associated with heme might be readily degraded by proteolytic enzymes as compared with holoenzymes (Fig. 3). It was reported that the turnover of heme moiety of cytochrome P-450 was faster than that of cytochrome P-450 apoprotein (Rajamanickam

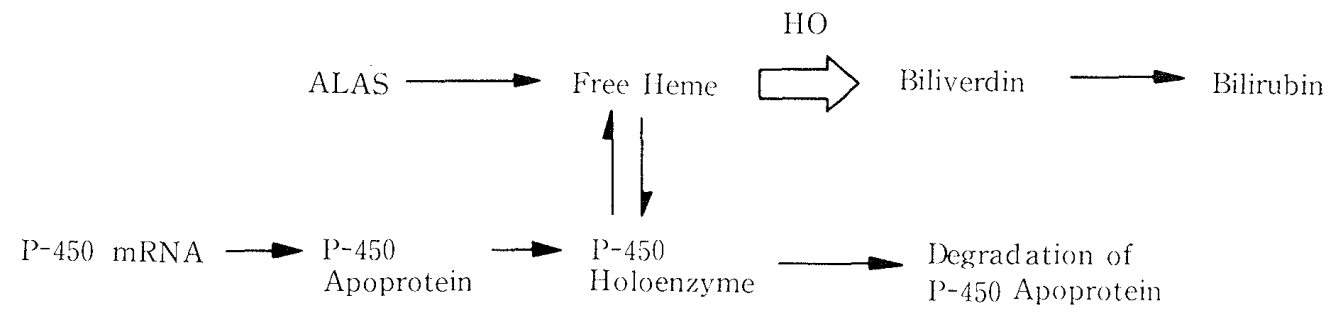

Fig. 3. Hypothesis concerning the reduction of microsomal cytochrome P-450.

ALAS: $\delta$-aminolevulinic acid synthase, HO: heme oxygenase. 
et al., 1975). Exchanges of heme moieties between holoenzymes and free heme pool actually occur under physiological conditions (Sadano \& Omura, 1983). In tumorbearing mouse livers, heme released from cytochrome P-450 is metabolized rapidly by elevated heme oxidation activity. As a result of the degradation of heme, less association of free heme and cytochrome P-450 apoprotein occurred in tumor-bearing mouse livers. The reduction of $\delta-\left[{ }^{14} \mathrm{C}\right]$-ALA incorporation into microsomal proteins as reported by Beck et al. (1982) was probably due to the rapid degradation of $\left[{ }^{14} \mathrm{C}\right]$-labeled heme in tumor-bearing mouse liver. It is, however, unknown whether the rate of association between heme and cytochrome $\mathrm{P}-450$ apoprotein is a rate-limiting step of the turnover of cytochrome P-450.

\section{Acknowledgments}

We are greatly indebted to Miss S. Ogai for preparing this manuscript. This work was supported in part by Grants-in-Aid for Cancer Research from the Ministry of Education, Science and Culture, Japan.

\section{References}

Aviv, H. \& Leder, P. (1972): Purification of biologically active globin messenger RNA by chromatography of oligothymidylic acid-cellulose. Proc. Natl. Acad. Sci., 69: 1408-1412.

Beck, W. T., Dedmon, M. L. \& Ouellette, M. A. (1982): Biochemical basis for impared drug metabolism in tumor-bearing rats. Biochem. Pharmacol., 31: 1535-1543.

Chamberlain, J. P. (1979): Fluorographic detection of radioactivity in polyacrylamide gels with the watersoluble fluor, sodium salicylate. Anal. Biochem., 98: 132-135.

Chen, Y. T. \& Negishi, M. (1982): Expression and subcellular distribution of mouse cytochrome P1-450 mRNA as determined by molecular hybridization with cloned $\mathrm{P}_{1}-450$ DNA. Biochem. Biophys. Res. Comm., 104: 641-648.

DeMatteis, F. \& Gibbs, A. (1972): Stimulation of liver 5-aminolevulinic acid synthetase by drugs and its relevance to drug-induced accumulation of cytochrome P-450. Biochem. J., 126: 1149-1160.

Guenthener, T. M. \& Nebert, D. W. (1978): Evidence in rat and mouse liver for temporal control of two forms of cytochrome P-450 inducible by 2,3,7,8-tetrachlorodibenzo-p-dioxin. Eur. J. Biochem., 91: $449-456$.

Haugen, D. A., Coon, M. J. \& Nebert, D. W. (1976): Induction of multiple forms of mouse liver cytochrome P-450. J. Biol. Chem., 251: 1817-1827.

Higashi, K. \& Ikeuchi, K. (1983): Altered distribution of constitutive forms of microsomal cytochrome P-450 in tumor-bearing mouse liver. J. UOEH, 5: 155-161.

Huang, M. T., West, S. B. \& Lu, A. Y. H. (1976): Separation, Purification and properties of multiple forms of phenobarbital-treated mice. J. Biol. Chem., 251: 4659-4665.

Kato, R., Takanaka, A., Takahashi, A. et al. (1968): Drug metabolism in tumor-bearing rats. Jap. J. Pharmacol., 18: 224-244.

Laemmli, U. K. (1970): Cleavage of structural proteins during the assembly of the head of bacteriophage T4. Nature, 227: 680-685.

Lowry, O. H., Rosebrough, N. J. \& Farr, A. L. et al. (1951): Protein measurement with the Folin phenol 
reagent. J. Biol. Chem., 193: 265-275.

Maines, M. D. Kappas, A. (1975): Cobalt stimulation of heme degradation in the liver. J. Biol. Chem., 250: $4171-4177$.

Nakata, Y., Suematsu, T., Nakata, K. et al. (1964): Activities of various aminotransferases in tumorbearing rats. Cancer Res., 24: 1689-1699.

Omura, T. \& Sato, R. (1964): The carbonmonoxide-binding pigment of liver microsomes. J. Biol. Chem., 239: 2370-2378.

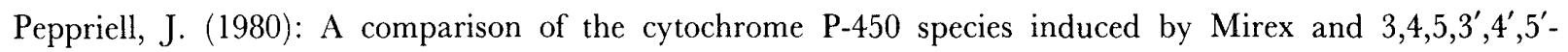
hexachlorobiphenyl in hepatic microsomes of the mouse. Environm. Res., 23: 309-318.

Rajamanickam, C., Rao, M. R. S. \& Padmanaban, G. (1975): On the sequence of reactions leading to cytochrome P-450 synthesis - effect of drugs. J. Biol. Chem., 250: 2305-2310.

Raw, I. (1983): Effect of extra-hepatic Walker sarcoma 256 on the synthesis and degradation of liver cytochrome P-450 synthesis-effect of drugs. J. Biol. Chem., 250: 2305-2310.

Ryan, D. E., Thomas, P. E., Korzeniowski et al. (1979): Separation and characterization of highly purified forms of liver microsomal cytochrome P-450 from rats treated with polychlorinated biphenyls, phenobarbital, and 3-methylcholanthrene. J. Biol. Chem., 254: 1365-1374.

Sadano, H. \& Omura, T. (1983): Reversible transfer of heme between different molecular species of microsome-bound cytochrome P-450 in rat liver. Biochem. Biophys. Res. Comm., 116: 1013-1019.

Sassa, S., Kappas, A., Bernstein, S. et al. (1979): Heme biosynthesis and drug metabolism in mice with hereditary hemolytic anemia. J. Biol. Chem., 254: 729-735.

Schacter, B. A. \& Kurz, P. (1982): Alterations in hepatic and splenic microsomal electron transport system components, drug metabolism, heme oxygenase, and cytochrome P-450 turnover in MurphySturm lymphosarcoma-bearing rats. Cancer Res., 42: 3557-3564.

Schacter, B. A. \& Kurz, P. (1984): Alterations in hepatic heme and cytochrome P-450 metabolism in Murphy-Sturm lymphosarcoma-bearing rats. Biochem. Pharmacol., 33: 815-820.

担癌マウス肝に㧍けるへム代謝とチトクローム P-450 の代謝回転

池内 希恵 ·小原 政信・平野 英保・後藤 貞夫・東＼cjkstart監 産業医科大学生化学教室

要 旨：担癌マウス肝ミクロソームのチトクローム P-450 含量の減少の機構を明らかにするため に肝におけるへム代謝，およびチトクロームP-450の生合成を調べた。へム合成の律速

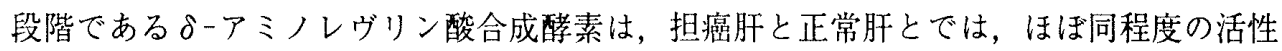
を示したが，へム分解を律速する酵素として知られるへムオキシゲナーゼは，担癌肝で促 進していた，次に，肝の膜結合型ポリソームより得たポリ $(\mathrm{A})^{+} \mathrm{RNA}$ を, in vitroの蛋白質 合成系に加え, $\left[{ }^{35} \mathrm{~S}\right]$-メチオニンでラベルされた産物をSDS-ゲル電気泳動法で分析すると 担癌肝より抽出したポリ $(\mathrm{A})^{+} \mathrm{RNA}$ の中で, チトクロームP-450 の mRNA が減少している ことを示唆するような結果は得られなかった。これらの結果は, へム合成の低下や，千卜 クローム P-450の mRNAの減少が, 担癌マウス肝に抢けるミクロソームのチトクローム P-450の直接の原因でないことを示唆している.

J. UOEH（産業医大誌), 7 ( 3 ): 269-277 (1985) 